\title{
RELATION OF THE CAPITAL STRUCTURE AND PROFITABILITY BASED ON LITERATURE
}

\author{
Földi Péter \\ Student, School of Economics and Social Sciences, Szent István University, Gödöllő \\ E-mail: foldi.peter89@gmail.com
}

\begin{abstract}
The corporates are regularly forced to use different inner and external capital elements in their life. Of Course, the companies will use that kind of sources, which they are able to achieve a value-creation progress with, thereby contribute to the increment of the trade industry sector. According to many literatures, the income-generating's ability of the enterprises can be affected by the major financial's decisions, following the inner and external financing opportunities, strategics, forms and principles, and the capital structure of all these. Of course, we can make differences among the lifecycles of the corporate's life. The small and medium sized enterprises need to have capital for the fluently running, but it is, that from where and how it is available. The capital structure theories helps us to understand this wide range of consequences. There are also two differencies between the creator's outlook of the traditional and the new capital structure theories. Modigliani-Miller theorems are classified into the new capital structure theories, where there are no taxes originally, but the effects of the taxes are already taken into count by the modified theories.
\end{abstract}

Keywords: Capital structure, profitability, capital structure theories, inner and external capital elements, corporate life cycles

JEL classification: $G 32$

\section{Introduction}

To start-up and operate a business is needed capital from the owners. The venture get assets with capital investment. The capital it can be coming from the owners and lenders also. The capital shows, that where it comes from and how much of the purchasing power, which is held by the contractor acquires assets necessary to begin or resume the activity, as well as a source of business growth.

No exists one theory for the optimal level of composition of the capital structure, which could determine clearly that what is acceptable in the individual industry sector and what is not. Presumably in the company's life, there is an optimal ratio of debt stock, which can be between 65 and 70 percentage. When the company reach this level, we can stop to increase debt, because on this upper level (70 percentage), the lenders will wait bigger yield irrespectively of the company profit capacity. In this situation the lenders can be motivated to stay in the company in the following time/years, or if the company get worth, the lenders can get out of any losses. When the company exceed the optimal ratio of debt level, evidently the banks can not grant money for the company, until the banks do not realize just the pieces of loans, or nothing of the money. It will be unprofitable to the banks.

We can establish company without debt or foreign capital. In this situation we can say that the company operates of the owners capital. We can not base the company's activity to work of debts merely. Nowadays, the foreign capital can able to complete the owners capital, what is 
needed for the company for operating. Sometimes, we can not finance all of the company's process with owners capital, because on the money-market we can realize profitable debts, and in this way we can develop the owners capital out of the company. In addiction to the previous situation In company's life, there is a term when the company wants to invest shares or it can not pay it's partners, because the company is out of the money. In this way the company also needs debt.

There are many types of debts, but it is not screw that the company impress of them. By some sources the debts can be sorted to refundable and non-refundable. The refundable debts contains other 3 types, what I introduce in the following. The non-refundable contains preferred stock and the utterance of ordinary share. The refundables contains the following 3 types, which includes Run finance (bill of exchange, trading loan), Indirect ((Bank loan, Factoring, Leasing), and Direct (Bond, Deposit ticket).

The internal finance elements contains: profit, depreciation, reduced working capital and the sale of invested assets. By another sources the external and internal capital elements are different that we can view by the following table.

Table1. The elements of internal and external financing

\begin{tabular}{|c|c|}
\hline INTERNAL FINANCING & EXTERNAL FINANCING \\
\hline $\begin{array}{l}\text { ("Public") self-financing } \\
\text { (by increasing equity reinvestment of } \\
\text { profit) }\end{array}$ & $\begin{array}{l}\text { Self -financing } \\
\text { (equity - enhancing existing owners) }\end{array}$ \\
\hline $\begin{array}{l}\text { Amortization } \\
\text { ("Secret self-financing" does not appear } \\
\text { on the balance sheet) }\end{array}$ & $\begin{array}{l}\text { Share of Funding } \\
\text { (raising new equity owners) } \\
\text { • Extern share capital increase (eg .: capital increase } \\
\text { through by public issue of shares) } \\
\text { - Involving Risk Capital (Private Equity) }\end{array}$ \\
\hline $\begin{array}{l}\text { Employees (profit) share } \\
\text { (equity) }\end{array}$ & $\begin{array}{l}\text { Equity loan (current owners) } \\
\text { (source of foreign creditors' rights) }\end{array}$ \\
\hline \multirow[t]{2}{*}{$\begin{array}{l}\text { Equity release (property transfer) } \\
\text { (existing fixed or rotating equipment } \\
\text { mobilization, or the sale or hire) }\end{array}$} & $\begin{array}{l}\text { Foreign funding } \\
\text { - bank loans, } \\
\text { - shape foreign policy source }\end{array}$ \\
\hline & $\begin{array}{l}\text { Hybrid Financing } \\
\text { (the combination of shareholder and creditor rights) } \\
\text { - convertible, option bond }\end{array}$ \\
\hline
\end{tabular}

Source: Katits (2002), 25 p.

\section{Material and method}

Equity can be from two sources. One source is that the owners welth permission, and the other one is that the company realizes profit before the years and the owners can not take out of the company. The owners submit the founders capital and the capital surplus for the company.

The entrepreneur's equtiy equals to the amount of the company's capital, if the entrepreneurs equity financed by the shareholders, and members. The owners additional welth permission to the equity is define as that the company reaches profit before the years, and the owners allow of the part, or all for the company. 
The company capital structure means the ratio of long-term liabilities and long-term equity. The company's financial activity is a complex task, which involves the examination of investment, investment opportunities, investment selection decisions between the possible. And the establishment of short and long-term financial, operational and strategic funding decisions, organizing the financing, managing financial relationships with different partners.

One of the main task of the company financing is to provide to the require capital for the company's working process on long-term. The amount of company's value, profitability the return of assets and the efficiency of sources can be influenced by the acquration and the use of long- and short term sources which needs for the investment and the finance of the current assets. (Herczeg, 2009. 6. pp.)

The financing section of the companies happens at different stages of their life cycles:

- In the company's start-up and increasing section, it needs more and more capital, and as a rule that in this time the company pofitability capacity is low.

- The preparing section of the company financed by the seed capital.

- To start up a company (and gain impuse) it need starter capital, and your company's products and services to sell too.

Seed capital is tipically used in the company's preparing section. In this time the risk is big, and for the financing the risk capitalist's get rights for the proprietary shares. In the following I would like to present the external capital and debt elements of the institutionalized financing forms.

Kovács (2012) says: "Business angels, that investors, who buy up the innovative company's in the beginning of it's process, or provide the seed capital for its. This sector's partners will be probably become from simlpy investors, patent mandatory of micro-company's, who hasn't got any money, any plan, and management to make several utilization, and there is not any spiritual capital anyway. The know-how speciality, or later the business monopol rigths will going to provide the return."

Bank loan needs to the increasement and the running tendency.

This includes the purchase of fixed assets, the use of innovation and R \& D.

The company needs venture capital, when it hasn't got any bank loans, that on the one hand the higher rate is risky, the company do not fill a long time in the sector. On the other hand, start up enterprise can not get any money from banks, because the company hasn't enough capital, profit and experience. This capital demand check in the bank loans, where the investment amount get bigger. The venture- and private capital investments are economic, when the company gets money in the financing progress. So in this way the ratio of the venture- and private capital which finance(s) the company's beginning, expansion, and the change of proprietary circle.

On the company's fast increasing, and expand section primarily has liquidity problems, and needs more capital to improve.

If the owners can not withdrow capital to the process, then they have to go to public capital issue, and begin to stock market. However this financing form insure profit expectation, which causes the investors to invest money to the company. 
In the previous section, we could see the capital necessity forms from a starter to a booming company. Every company has a different financing form, which depends on its size, profit- and yield expectations.

The aim of the financial leader is a form of a capital structure, where the company can be maximalize their value. For this step, the leader needs external environmental experience, which the company reaches at the optimal capital structure level.

The measurement of the capital structure could be define by some theories. The operational leverage index shows us that the company's profit growth and the sale growth.

These growth(s) are depend on the ratio of fixed and variable costs.

This index shows us, the profitability when the fixed costs are high.

$$
\begin{aligned}
& \mathrm{DOL}=\text { gross margin } / \mathrm{EBIT} \\
& \text { EBIT - earnings before tax }
\end{aligned}
$$

The investors leverage report, where there is not any money for the transactions on the investment. (Sulyok-Pap 1995, 309. pp.)

\section{The determining factors of the capital structure}

The classical capital structure theories, which are working with the optional capital politics, and the defining of the company's value, which was made by Modigliani-Miller.

According to the traditional capital strucrure theories, there are two different valuation method in the defining of the company's shares.

- The first type of the name is the so-called method NOI (Net operating income). It is based on the discounted value of the company operating profit equals to the aggregate value of the cost of capital shares and bonds.

- The second method is called NI (Net Income), which, in turn, net profit, which takes into account the reduced interest income associated with the bond subjects in the present value calculation for the capital cost. With this, we can calculate the value of the shares, while the company's value can be determined of the value of the shares, which are added to the value of bonds.

There are two differences between the traditional and the new capital structure theory creators outlook. The creators of the traditional theory and the new capital structure theory, we can notice two differences between them. The first difference is that what method they can use, the other hand, that how they imagine the evolution level of capital expenditure for the discounted leverage depends on.

The traditional theory assumptions are the following (Krénusz, 2007):

1. The company's business risk is constant.

2. Each company asset risk and fixed assets are constant.

3. Cash flow is stable such as perpetuity.

4. There are no taxes.

5. There isn't preferential share issue. 
6. There are no transaction costs.

7. The expectations are homogeneous.

8. Only two devices are available in the financing section: Credit and ordinary shares, both of which are possible at any time involvement.

The traditional theory creators made some changes on the NI method, because their opinion was that the method is acceptable. These changes were not in the base of the method, but basicly the amount of the capital cost(s) which depends on the venture capital and the profit. The authors stated the following, that the increasing loan enrolment level growing the company's value at a critical capital structure level. If this critical point reaches or put off the company's value decrease because the increased result is equilibrate to the increasing profit value.

The financing has two effects, which contains revised net present value, and the revised discount rate, called by WACC method. /In the following/, I would like to present these now.

The net profit theory suppose that the company has two chances, when its begin or continue its activity. These chances the requisition of equity (re) and debt (rd), which cause costs, what I would like to show in the Figure 1.

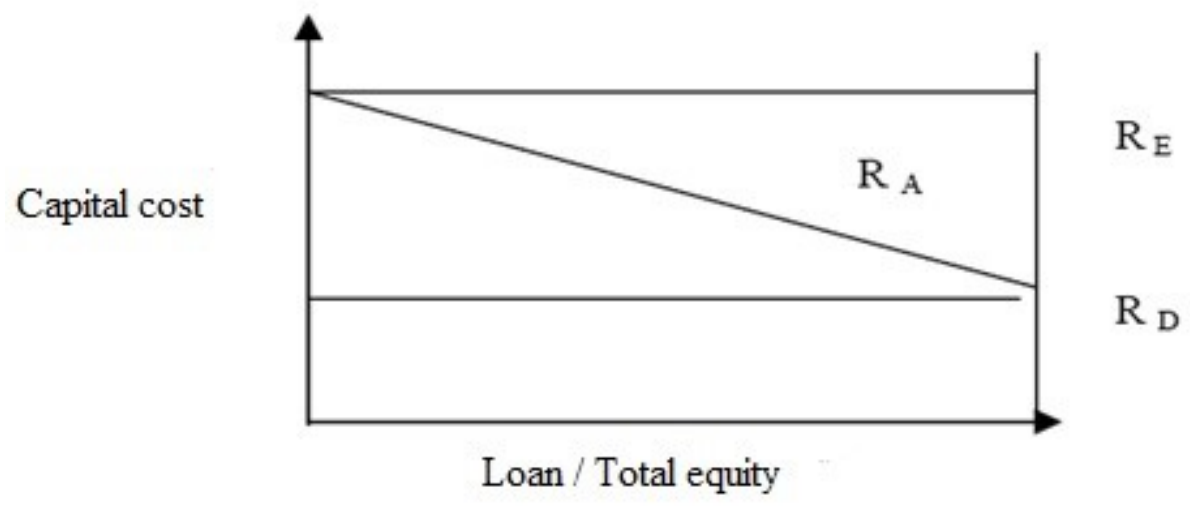

Figure 1. The theory of capital structure of net income (before taxes) Source: Bárczi (2010), 36 p.

Due to the prevailing high rates the use of equity is more expensive than the debt, so that it is more preferable. When a company can not capable to get debt, we can use the equity watchful. We have to notice about the ratio of debt, because the increasing debt amount causes that the company's value to increase.

The continuous process of the small and medium-sized enterprises need capital, which is important that the source where and how is available. For this, I will examine the ordinary- and the foreign capital costs, which are in given structure would be changeless. And I illustrate this on the Figure 2. 


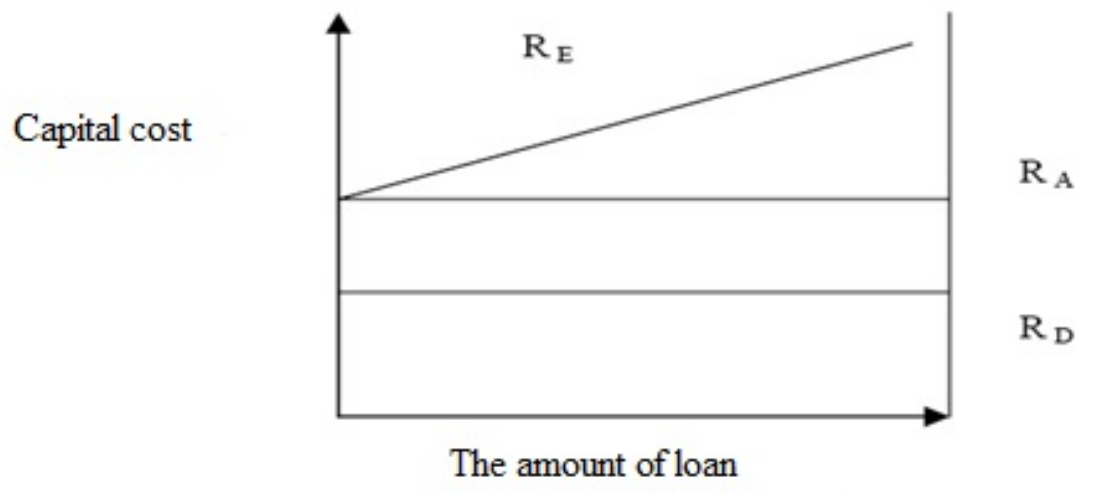

Figure 2. The net operating income theory of capital structure (before taxes) Source : Bélyácz (1997), 262 p.

The stock costs will be increase, when the company it going to increase(s) the relative weight of the foreign capital. The increasement of the indebtness causes that the owner capital cost increase, because this thing grow the risk, then the stockholders require more rate of return. An advanteg of the foreign capital is the lower cost, than the equity, which is compensated by the increasing costs. The ordinary capital cost and the company's value do not depend on the changes of the capital structure. (Bárczi, 2010)

There is not any optimal capital structure, which increase the company's value with the ratio of equity and debt during the finance.

The traditional theory shows us, the transition between the net operating income and the net income theory. The theory assumption of is that the stock capital cost is bigger than the equity capital cost, which causes the the foreign capital financing is not risky, which is shown on Figure 3.

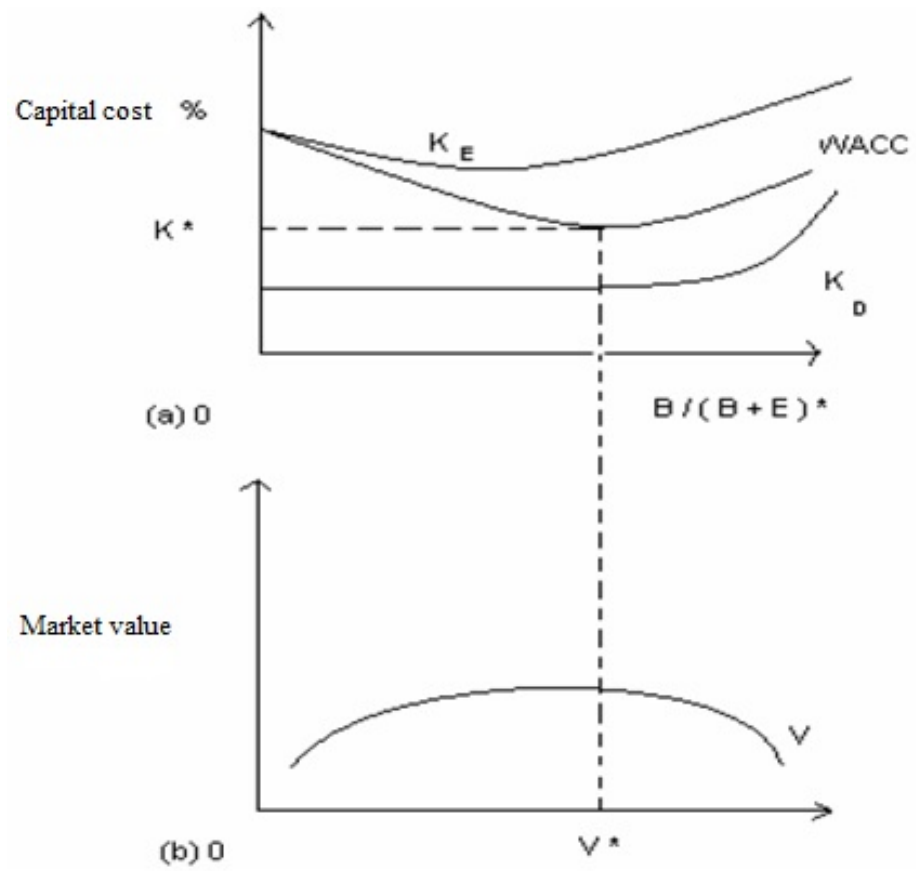

Figure 3. Cost of capital, capital structure and corporate value

\section{Source: Illés (1999)}


The foreign capital cost in the beginning is constant, but the increase rate of the venture, causes that the debt is growing, that the loans taxes require bigger risk, because the risk increased.

However, the cost of equity capital increases when the leverage ratio increases, so the average cost of capital WACC will be U-shaped curve, so the ratio of debt and equity has an optimal level, where the average cost of capital is minimal, while the company's value will be maximized. The theory suggest that there is an optimal capital structure, if we disregard the taxes.

The upper three theory contradict each other, which propose an unanswered question, even that the change in the capital structure effects to the company's value. The answer will be in Modigliani and Miller's 1958 theory, that the two creators theorem formulated in the corporate capital structure and cost of capital in relation to the impact on the company's value. According to their views on the base of the illustrated three theories, which can make an objection closer to the net operating income.

Bárczi $(2010,38$. pp.) say's: "If all of the company financed by equity, then this is the expected profit of the assets, that is the company capital structure is equal to the expected profit of the stocks. If the company cases debt, then the capital structure from the stockholders and the creditors added as the weighted average of the expected profits, where the weights corresponding to the company's venture."

(1.) MM theorem states, that dividend policy does not train to the company's value, because it can determine by the profit capacity of the assets under pure market conditions. (Borszéki, 2008)

Krénusz (2007) says: „As a result, that the pure market rate is independent of the company's capital source, and arrange with the profit of company's who financed by stocks in the same solid class."

The company's value is independent of its capital structure, when we suppose perfect capital market, and there is not taxes. The transcription causes that the ratio of loans increase, whereby the stockholders expectations about the profit get bigger. When the company gets newer loan, the stockholders risk get high, therefore in this condition when the risk is high, the creditors expect bigger profit.

$$
r_{A}=\frac{D}{D+E} \bullet r_{D}+\frac{E}{D+E} \bullet r_{E}
$$

Where: $\quad \mathrm{rA}=$ corporate cost of capital,

$\mathrm{D}=$ debt,

$\mathrm{E}=$ equity,

$\mathrm{D} /(\mathrm{D} / \mathrm{E})=$ ratio of debt (bonds),

$\mathrm{E} /(\mathrm{D} / \mathrm{E})=$ ratio of shares,

$\mathrm{rD}=$ expected return on debt,

$\mathrm{rE}=$ expected return on equity.

Capital cost is the profit of the all assets, which can be also determine as the weighted avarage of the expected profit of the equity and debt. We can get the capital cost by the quotient of the 
operatinal result and the all of assets, but we can calculated by the weighted avarage profit of the odd capital elements.

(2.) MM theorem the venture company's expected profit of shares proportionately increase with the capital quotient which is calculated by on market value. And the measure of growth depends on the difference of the profit of ordinary capital cost and debt. (Borszéki, 2008)

In other words, the original formula is applied:

$$
r_{A}=\frac{D}{D+E} \bullet r_{D}+\frac{E}{D+E} \bullet r_{E}
$$

And we finally get the corrigated formula with taxes:

$$
r_{E}=r_{A}+\frac{D}{E} \bullet\left(r_{A}-r_{D}\right)
$$

Where: $\quad \mathrm{rA}=$ corporate cost of capital,

$(\mathrm{D} / \mathrm{E})=$ ratio of debt (bonds) and equity,

$\mathrm{rD}=$ expected return on debt,

$\mathrm{rE}=$ expected return on equity.

\section{Results and discussion}

The own stocks value increase when the debt growth. This method gives a chance that we can be indebtness because that's a good business. but is not, because the debt's profit depends on the indebtness. When the owing rate overstep particular ratios, cause an increasing process after the debt. The creditors risk depends on the increasing ratio of debt, then the equity's profit is not independent from the ratio of the equity and debt. When we can increase the ratio of equity and debt, then the profit of equity is slow. When the company debt's substance increases, than the profit of the equity increase slowly.

MM 2. theorem still valid, when the loan risk-free, and still a ratio when the rate risk premium does not change. (Bárczi, 2010, 43. pp.)

Weighted avarage capital cost can be determine as the company's expected profit of all stocks, which contain(s) portfolios.

$$
W A C C=\frac{D}{D+E} \bullet\left(1-T_{c}\right) \bullet r_{D}+\frac{E}{D+E} \bullet r_{E}
$$

Where: $\quad \mathrm{D}=$ debt,

$\mathrm{E}=$ equity,

$\mathrm{D} /(\mathrm{D} / \mathrm{E})=$ ratio of debt (bonds),

$\mathrm{E} /(\mathrm{D} / \mathrm{E})=$ ratio of shares,

$\mathrm{rD}=$ expected return on debt,

$\mathrm{rE}=$ expected return on equity,

$\mathrm{Tc}=$ corporate tax rate. 
We take notice of using WACC, when we calculate the company's value and the profit of the debt which depends on the capital structure. The loan cost after tax will be smaller than the original formula rA. Hereby the new estimated capital cost expresses loans with tax savings.

References:

1. Bélyácz I.: Tőkeberuházási és finanszírozási döntések 1997, Pécsi Tudományegyetem Kiadó

2. Brealey-M.: Modern vállalati pénzügyek, 2005, Panem Könyvkiadó

3. Dr. Bárczi J.: Alkalmazott vállalatértékelés 2010, Szent István Egyetemi Kiadó

4. Dr. Borszéki É.: Vállalati pénzügyek jegyzet. 2008, Szent István Egyetemi Kiadó

5. Dr. Katits E.: Pénzügyi döntések a vállalat életciklusaiban, 2002, KJK-Kerszöv

6. Dr. Kovács Z.: Innovációs folyamatmenedzsment 2012, Nyugat-magyarországi Egyetem

7. Herczeg A.: Optimális tőkestruktúra meghatározása a tőkeelmélet fejlődési szakaszaiban, 2009. Doktori értekezés Debreceni Egyetem

8. Illés I.: Társaságok pénzügyei 1999, Saldo Pénzügyi Tanácsadó és Informatikai Rt.

9. Krénusz Á: A vállalati tőkeszerkezet meghatározó tényezőinek új Modellje és annak vizsgálata Magyarország példáján. 2007

10. Sulyok-Pap M.: A vállalati tõkeszerkezet kérdései 1995, Új utak a közgazdasági, üzleti és társadalomtudományi képzésben, BKE Jubileumi konferencia 